\title{
Fulcher, Jane F. 2018. Renegotiating French /dentity: Musical Culture and Creativity in France during Vichy and the German Occupation. Oxford: Oxford University Press.
}

\section{Reviewed by Zachary Lee Nazar Stewart}

Renegotiating French Identity represents the most recent stage of Jane F. Fulcher's monographic march through French history, and comes in the midst of a marked expansion in music-historical research on France during the Second World War. Fulcher begins by surveying the political and institutional circumstances of occupied France, before examining how individual musicians interacted with wartime authorities and participated in the contestation of French identity. Her subjects include Pierre Schaeffer, Arthur Honegger, Francis Poulenc, and Olivier Messiaen, not to mention a host of secondary figures, whose wartime activities have been described unevenly in the existing literature. In each chapter, Fulcher's examination of individual musicians clarifies the affordances and difficulties of the environments in which they worked, and she tacks between illuminating individuals through contextualization and understanding contexts through individuals. Although Fulcher offers new insights into each figure, the book aspires to present a group portrait rather than a set of individual studies. It details the modes of being a musician available under occupation, and the musical and political choices made by musicians in an era that, like ours, demands to an unusual extent that choices be made.

Fulcher's monograph constitutes a substantial addition to a small but growing body of English-language scholarship on the era, joining exemplary recent studies such as Leslie Sprout's The Musical Legacy of Wartime France (Sprout 2013) and Sara Iglesias' Musicologie et Occupation (Iglesias 2014; see also Chimènes and Simon 2013; Simon 2009; and the classic Chimènes 2001). No doubt some of the reasons for this recent expansion in research on music in wartime France stem from long-standing and growing disciplinary preoccupations: music beyond the mid-century avant-garde; situations in which music and politics have interacted in an especially acute manner; and an awareness of the constructed nature of identity. Other reasons are more immediate, as music historians have begun to explore the intertwining of music and war in a variety of contexts (for instance, Fauser 2013), and to explicitly discuss the ethical dimensions of music-making. Some of the more prominent 


\section{Current Musicology}

characteristics of wartime France, moreover, have proved eerily and increasingly familiar: authoritarian deployment of state power; massive propaganda and disinformation; and xenophobic, nationalist, and conservative political movements. Fulcher's monograph has thus been published in an era that increasingly resembles that which she studies. Its themes and concerns are our own, transposed onto a setting that may be novel to many readers but which is beginning to attract wider disciplinary attention.

Renegotiating French Identity primarily offers a chronological rather than methodological extension of Fulcher's three previous monographs. Her materials, and the ways she approaches her materials, have in general remained consistent. She has always sought to explore the confluence of music and political thought, described variously in the titles of her monographs as "politics" (Fulcher 1987), "cultural politics" (Fulcher 1999), "ideology" (Fulcher 2005), and now "identity" (Fulcher 2018). The terminological progression is striking: Fulcher's titles seem to serve as a barometer of critical discourse among culturally-oriented music historians. The theoretical discussions of the present monograph, notably those based on the work of Pierre Bourdieu, move within the boundaries of her introduction to The Oxford Handbook of the New Cultural History of Music (Fulcher 2011), but Fulcher focuses on historical materials rather than theory.

Between its defeat in 1940 and liberation in 1944, France was governed partly by German occupiers based in Paris, and partly by a French administration based in Vichy and led by Marshal Philippe Pétain. Most French people were initially supportive of the Vichy administration, but over the course of 1941 and especially 1942 the willingness of Vichy to make concessions to, and even anticipate the demands of, the Germans grew evident. Public opinion shifted accordingly, and it became clear that one could not simultaneously support Vichy and oppose the Germans. The dichotomy between German occupiers in Paris and French administrators in Vichy consequently belies the complexity and dynamism of the situation. Conditions remained unstable as the occupation deepened: the nature of Pétain's regime shifted, its façade of independence collapsed, and German dictates became increasingly brazen.

Fulcher devotes her entire opening chapter to the "essential political and institutional background" of French wartime music-making, as well as to methodological considerations. It includes detailed discussions of shifting Vichy politics and ideologies, Vichy cultural institutions, the German administration in Paris, and the possibility of musical resistance, as well as Fulcher's conception of "French identity," discussed below. The necessity of studying institutions in 
order to make sense of music-making in wartime France should, after Fulcher's study, be beyond question. A lengthy institutional exposition independent of the case studies, however, is hardly necessary given that subsequent chapters include sufficient context to be understood on their own. Nonetheless, the chapter does signal Fulcher's aspiration to provide a systematic foundation for future research, and may prove to be a valuable collection of information for students of Vichy cultural institutions.

Not content with providing contextual information, Fulcher also puts forward methodological prescriptions in her opening chapter, often as direct injunctions to the reader. She notes, for instance, that "it is imperative to follow the developing awareness and strategies of figures like Roger Désormière and Pierre Schaeffer as the regime ineluctably progressed in its program of collaboration" (13). Fulcher thus provides an historical, conceptual, and methodological framework to be deployed both in the remainder of her monograph as well as by other researchers, a system within which to think about occupation music-making. As a result, she broadens her potential readership to include those interested in music during the occupation but unfamiliar with the trajectory of the period. Unfortunately, however, the opening chapter lacks a comparative dimension. Fulcher's discussions of censorship, individual agency, resistance, and the lack of stylistic dictates would have benefited from a sustained engagement with the literature on Nazi Germany. The comparison appears natural given the German occupation, and may have been especially illuminating given that each regime encountered difficulties in prescribing or regulating musical style, resulting in occasional aesthetic incoherence and disconnects between policies and styles.

Fulcher is especially concerned with the ways in which the musical materials of the era were mediated and presented to their original audiences, that is to say, with paratextual as well as contextual considerations. Writing generally about paratexts and contexts, she emphasizes "the role that varying instantiations or inscriptions of works-through methods of performance, textual framing, recording, and means of staging or presentation-may play in inflecting their message or their specific enunciation" (8). Paratexts and contexts prove central to the volume's most compelling example of the renegotiation of French identity, the discussion of Pelléas et Mélisande in the second chapter. There Fulcher examines how Vichy officials, German occupiers, and French resisters offered competing conceptions of the cultural significance of Debussy's symbolist opera. Like Berlioz's equally polyvalent La Damnation de Faust, also performed during the occupation, Pelléas et Mélisande could be construed to 


\section{Current Musicology}

emphasize either Franco-German cultural collaboration or French classicism, which Fulcher identifies as central to resistance aesthetics. The liner notes accompanying a 1942 recording of the opera, promoted by occupation authorities, emphasized a Franco-German interpretation. To Fulcher's ears, however, conductor Roger Désormière offered an opposing, classically French performance by emphasizing textural clarity and downplaying the opera's leitmotifs and, thus, its Wagnerism. As the case of Pelléas et Mélisande suggests, Fulcher's insistence on contextual specificity allows her to connect broad political phenomena to her interpretations and analyses of individuals' compositions and artistic and political decisions.

Understanding wartime France requires contextual knowledge on a granular level, given the distinct geographical zones of Vichy governance and German occupation, the manifold and plastic cultural institutions, and the shifting public awareness of and reaction to policies. At the core of her study, then, are the relationships between individuals and institutions, and the fluid symbolic matrices through which musical, cultural, and political assertions become meaningful. The celebrated French sociologist Pierre Bourdieu provides the theoretical foundation for her approach. In the introduction to her Oxford Handbook of the New Cultural History of Music Fulcher describes Bourdieu as "reembedding cultural analysis within the social" and as having "allowed us to identify political power in systems of representation" (Fulcher 2011, 6). From this perspective, particular symbols or aesthetic characteristics function as analogues to political positions, albeit not in a simplistically codified or mechanical fashion. As a result, processes of cultural contestation may be understood as helping to legitimize and delegitimize the German occupiers, the Vichy government, and their ideologies. In music, Fulcher argues, "contestation can occur through traditional genres, forms, and styles, the logic of which can be challenged by strategies that open up or disrupt the language" (Fulcher 2011, 7). The methods and theoretical insights of the "new cultural history of music" are now so sufficiently well-established as to negate the modifier "new," but they remain capable of supporting sophisticated analysis.

Subsequent chapters on the wartime actions of Pierre Schaeffer (Chapter Three) and Arthur Honegger (Chapter Four) explore how individual musicians worked within Vichy and occupation institutions to wildly divergent ends. Working for Radio-Vichy, Schaeffer had been assigned to broadcast youthoriented material that he came to understand as cultural propaganda. As he gradually realized that the "new France" that Vichy intended to construct would not align with his values and sense of French identity, Schaeffer surrounded 
himself with a group of like-minded musician-technicians and began to undermine his own programs. He sought to effect internal institutional resistance through his choice of texts and materials, their contexts, and their means of transmission, thus propagating a divergent sense of what French culture meant and could be. Fulcher points, for instance, to his collaborative Portique pour une jeune fille de France, for a 1941 celebration of Jeanne d'Arc, as subversive in its purposeful heterogeneity of content and presentation. Portique alternately employs contemporary and historical styles, and at different times the spectacle frames itself as occurring in the present and in the past. Like the Vichy officials who reacted negatively to Portique, Fulcher understands the broadcast as intentionally resisting the creation of a single youth community united behind Vichy's cultural objectives. In her interpretation, then, the heterogeneity of Portique worked towards anti-hegemonic, rather than specifically anti-Vichy, ends. However, the composition did include more directly oppositional elements, such as allusions to the music of the French Revolution, which epitomized the liberal, secular thought to which Vichy was opposed.

Schaeffer's subsequent acoustic experiments, many conducted in his Studio d'Essai, included recording people in diverse "sonorous architectures," the regulation of reverberation, assemblages of de-contextualized noises ("simulacres"), and study of the inevitable distortions involved in vocal reproduction (under the rubric of "haute fidélite"). Even if Schaeffer did not deploy all of these techniques for resistant purposes, Fulcher argues that they were developed in response to his recognition that the mediation of radio necessarily inflected the meaning of texts broadcast on it. She thus posits that these sonic and acoustic tools, developed by Schaeffer as he sought means of resistance, led directly to his influential postwar innovations. Schaeffer's wartime experiments offer an intriguing acoustic parallel, albeit one unexplored by Fulcher, to Fredrich Kittler's discussion of the slippage between military, civilian, and artistic applications of novel optical techniques and technologies during the Second World War (Kittler 2010).

Like Schaeffer, Arthur Honegger worked within the collaborationist sphere but, unlike Schaeffer, Honegger never effectively resisted its demands. With German and Swiss parents, but having established his professional life in France, Honegger offered in his own person a symbol of Franco-German affinity and of Hitler's "new Europe," a continent to be led by Germans and dominated by German culture. He was accordingly fêted and his compositions honored by the occupation authorities. Honegger allowed himself to be appropriated as a propaganda symbol, Fulcher argues, and consequently faced expulsion from the 


\section{Current Musicology}

resistant Front national des musiciens and censorship after the end of the occupation.

In the concluding chapters on Poulenc (Chapter Five) and Messiaen (Chapter Six), Fulcher places greater emphasis on music analysis, studying how these musicians effected or failed to effect resistance on a compositional level. Poulenc, unlike Honegger, consciously sought a resistant style and intentionally assumed a marginal wartime position in order not to be appropriated. Fulcher describes how Poulenc's well-received ballet Les animaux modèles (1942) failed as a resistant composition because it fit too readily within Vichy's vision of a traditionalist and predominantly rural France. Yet by drawing on models of literary resistance discussed in the underground press, Fulcher argues, Poulenc was subsequently able to project a competing and unambiguously anti-Vichy symbology and style, as in his Sonata for Violin and Piano (1943) and the cantata Figure humaine (1943).

Unlike Schaeffer or Honegger, Messiaen was not implicated in Vichy. He famously wrote his Quatour pour la fin $d u$ Temps while interred in a prisonerof-war camp in 1940 and 1941 following the surrender of the French army, and claimed to have never supported Pétain. Messiaen therefore had no record of collaboration to defend. He was, however, a devout Catholic, and sought to musically distance himself from the church, an institution initially supportive of Vichy. Messiaen's background in Catholic nonconformism, which emphasized the subjectivity of spiritual authority, provided him with the conceptual structure necessary to separate his beliefs from the dictates of the church. He thus strove to define a Catholic musical resistance and, Fulcher argues, to develop the means to reflect new subjective experiences. For example, she interprets the parataxis of the suite for two pianos Visions de l'Amen (1943) as a refusal of the possibility of a single spiritual authority. Instead, Fulcher suggests that Messiaen's suite instantiates the existence of multiple valid perspectives, offering a musical analogue to his nonconformist belief that the acquiescence of the Catholic Church need not invalidate the spiritual basis of his own resistance.

In a study that concerns itself with connecting personal decisions and broad cultural formations, defining different shades of French identity calls for a degree of finesse. Throughout the volume, Fulcher takes care not to reduce the amorphous and sprawling processes of identity construction to mere political functions, and eschews a misleadingly binary understanding of "identity" as either resistance or collaboration. For Fulcher, rather, identity construction occurs within local cultural structures: Désomière's interpretation of Pelléas et Mélisande refers musically to the same cultural heritage drawn on by the literary 
resistance; Messiaen's paratactic progression in Visions de l'Amen counters the Catholic church's claimed authority and its legitimization of collaboration; Poulenc's refusal to adhere to a single style in his Sonata for Violin and Piano negates the possibility of a single perspective and invites anti-authoritarian thought. In the broadest sense these aesthetic statements function to affirm distinctly French identities and discredit the ideologies behind collaboration, yet they also respond to local conditions.

These same narratives of identity construction, however, to some degree contradict the concept of "renegotiation" that Fulcher emphasizes in her title. "Renegotiation" suggests the possibility of compromise or resolution: one may negotiate a treaty or a stream crossing, for instance. Yet Fulcher describes the irreconcilable, not to say internally fragmented, cultural objectives of occupiers, resisters, and Vichy officials. These processes resemble war more than diplomacy, contestation more than negotiation. Negotiation does describe the processes by which individual musicians responded to their changing perceptions of Vichy, although Fulcher does not appear to be referring to this type of negotiation in her title. She recounts how Poulenc and Schaeffer followed this trajectory, only gradually arriving at opposition to Vichy and slowly developing effective means of musically articulated resistance.

The wartime activities of French musicians have been chronically understudied, to the benefit of some musicians and the detriment of others. Fulcher rightly argues that the difficulty of Poulenc's ethical realizations and compositional development do not diminish but rather enhance his stature. Her clear-eyed expositions of less complex cases likewise deserve credit: Désormière, for instance, actualized an unambiguous means of musical resistance as early as 1940, while Florent Schmitt, whose wartime activities have been too often obfuscated, collaborated at the highest levels. One of the unexpected pleasures of Renegotiating French Identity is its minor figures, not all of them musicians, whose recurrences perform much of the work of transforming the monograph into a portrait of the French musical milieu under the occupation. One thinks of Claude Delvincourt, Paul Éluard, Claude Roy, Gaston Gallimard, and so on, whose misadventures and ideological metamorphoses are detailed here and there in the main text and in the endnotes.

Fulcher has little interest in praising or sanctioning individuals, recognizing instead that the realities of working in environments like wartime France render efforts to assign guilt unenlightening. Extrajudicial musichistorical inquiries are endemic but hardly restricted to wartime France and Nazi Germany: "Scholars still embroiled in the controversy over whether 


\section{Current Musicology}

Shostakovich was acquiescent or a dissident may reconsider such dichotomies after examining contexts such as Vichy," Fulcher writes (240). Tortured attempts to adjudicate degrees of guilt often prove significantly less illuminating than efforts to elucidate the conditions that render guilt so difficult to determine. She brings similar care to the question of whether musical resistance is possible, which is necessarily linked to the question of its effectiveness. Unlike the armed resistance of the Maquis, literary and musical modes of resistance were necessarily subtle and thus risked ineffectiveness. Fulcher sometimes restricts herself to defining such questions and exploring their complexities: "Was the use of polyvalent meanings or symbols a true resistance act? Was destabilizing Vichy's symbols in itself resistance, even if not all could grasp this?" (68). At other times, she argues for particular positions: "there was a general agreement that art could awaken new political perceptions, in addition to inserting itself into the current ethical void" (258). She also opines on the priority of audience understanding over compositional intent: "we must draw a distinction between the author's apparent aspirations and the critical reception of a work in this period" (252). Fulcher thus engages sparingly but forcefully with ethical questions. At the end of her discussion of Honegger, for instance, she explicitly contemplates the obligations of artists to society and the relative importance of artistic and ethical imperatives, confronting the idea that art operates autonomously from politics. "Opportunism or political naiveté in the service of great art is not insignificant" (237), she avows.

Renegotiating French Identity offers a long overdue and impressively comprehensive account of French musical life under the Vichy administration and German occupation. The volume's analyses are invariably thoughtful and thought-provoking, particularly in the chapters on Poulenc and Messiaen. As appears to be Fulcher's intention, her ambitious monograph further opens up possibilities for music-historical research in a chronically under-explored field that raises archival, interpretive, and ethical questions that are as challenging as they are rewarding.

\section{References}

Chimènes, Myriam, ed. 2001. La Vie musicale sous Vichy. Brussels: Éditions Complexe. Chimènes, Myriam, and Yannick Simon, eds. 2013. La musique à Paris sous l'Occupation. Paris: Cité de la musique/Librarie Arthème Fayard.

Fauser, Annegret. 2013. Sounds of War: Music in the United States during World War II. Oxford: Oxford University Press.

Fulcher, Jane F. 1987. The Nation's Image: French Grand Opera as Politics and Politicized Art. Cambridge: Cambridge University Press. 


\section{Zachary Lee Nazar Stewart}

1999. French Cultural Politics and Music: From the Dreyfus Affair to the First World War. Oxford: Oxford University Press.

2005. The Composer as Intellectual: Music and Ideology in France, 19141940. Oxford: Oxford University Press. 2011. Introduction to the Oxford Handbook of the New Cultural History of Music. Oxford: Oxford University Press. 2018. Renegotiating French Identity: Musical Culture and Creativity in France during Vichy and the German Occupation. Oxford: Oxford University Press.

Iglesias, Sara. 2014. Musicologie et Occupation: Science, musique et politique dans la France des "années noires." Paris: Éditions de la Maison des sciences de l'homme.

Kittler, Friedrich A. 2010. Optical Media: Berlin Lectures 1999. Translated by Anthony Enns. Cambridge, MA: Polity Press.

Simon, Yannick. 2009. Composer sous Vichy. Lyon: Symétrie.

Sprout, Leslie. 2013. The Musical Legacy of Wartime France. Berkeley: University of California Press. 